\title{
Oral health associated with quality of life of people living with HIV/AIDS in Brazil
}

\author{
Gabriella Barreto Soares*, Cléa Adas Saliba Garbin, Tânia Adas Saliba Rovida and Artênio José Ísper Garbin
}

\begin{abstract}
Background: The epidemic of HIV/AIDS enters into its fourth decade and is still considered an important public health problem in developed and developing countries. The purpose is verify the oral health and other factors that influence the quality of life of people living with HIV/AIDS attending a public service reference in Brazil.

Methods: The participants answered the questionnaire on socio-demographic conditions, issues related to HIV and daily habits. The quality of life was analyzed by the HIV/AIDS Targeted Quality of Life (HAT-QoL) instrument with 42 items divided into nine domains: General Activity, Sexual Activity, Confidentiality concerns, Health Concerns, Financial Concern, HIV Awareness, Satisfaction with Life Issues related to medication and Trust in the physician. The oral health data were collected by means of the DMFT index, use and need of dentures and the Community Periodontal Index, according to the criteria proposed by the World Health Organization, by a calibrated researcher. Bivariate and multiple linear regressions were performed.
\end{abstract}

Results: Of the participants, 53.1\% were women and had a mean age of 42 years, $53.1 \%$ had eight years or less of schooling and $20.3 \%$ were not employed. In analyzing the quality of life domain of the HAT-QoL, with a lower average there was: Financial concern (39.4), followed by Confidentiality concern (43.2), Sexual activities (55.2) and Health concerns (62. 88). There was an association between the variables: do not have link to employment $(p<0.001)$, is brown or black $(p=0.045)$, alcohol consumption $(p=0.041)$, did not make use of antiretroviral therapy $(p=0.006)$, high levels of viral load $(p=0.035)$ and need for dentures $(p=0.025)$, with the worse quality of life scores.

Conclusion: Socioeconomic and inadequate health conditions had a negative impact on the quality of life of people with HIV/AIDS,

Keywords: HIV, Oral health, Quality of life, Health services

\section{Introduction}

Acquired Immune Deficiency Syndrome is considered an important public health problem in developed and developing countries. Worldwide, there are approximately 33 million people living with HIV/AIDS, and in Brazil, it is estimated that about 630000 individuals, 15 to 49 years old live with the disease [1,2].

After more than three decades since the beginning of the HIV/AIDS epidemic, significant improvements were observed for Antiretroviral Therapy (HAART). Because of those advances HIV has moved from a terminal illness to a chronic one [3]. With this, there was an improvement in the life expectancy of these people and the

\footnotetext{
* Correspondence: gabriella.barreto@yahoo.com.br

Postgraduate Programme in Preventive and Social Dentistry, Araçatuba

Dental School, Estadual Paulista University, Unesp, 1193 José Bonifácio Street, Vila Mendonça, Araçatuba, São Paulo, Brazil
}

quality of life (QOL) becomes an important instrument for assessing the health of these individuals [4].

In this perspective, Locker affirms that health problems can affect the quality of life, but it is not always the case [5]. The implication is that people living with chronic diseases, such as HIV, see the disease with a dimension that other problems, such as the presence of an oral condition, for example, do not always negatively influence their quality of life [6-8].

However, it is known that dental problems can impact the health of people with compromised immune systems $[9,10]$. These untreated illnesses can impair chewing and swallowing [11,12], directly affect nutrition and adherence of antiretroviral therapy [13], besides influencing physically, mentally and socially to the individual's life $[14,15]$.

\section{Biomed Central}

(c) 2014 Soares et al.; licensee BioMed Central Ltd. This is an Open Access article distributed under the terms of the Creative Commons Attribution License (http://creativecommons.org/licenses/by/2.0), which permits unrestricted use, distribution, and reproduction in any medium, provided the original work is properly credited. 
Few studies have been conducted that assessed the oral health status and quality of life of people living with HIV/AIDS. The present study investigated the quality of life associated with socio-demographic conditions, HIVrelated aspects, habits and the oral health of people living with HIV/AIDS attending the public service reference in Espírito Santo, Brazil.

\section{Methodology}

\section{Design study}

This is a quantitative exploratory cross-sectional and analytical study carried out in the public health service offered to people living with HIV/AIDS, the STD/AIDS Reference Center, which has operated since 1992 in the capital of Espírito Santo. Espírito Santo is a state located in southeastern Brazil and despite going through a major economic development, large social inequalities are observed.

Close to 1,500 people living with HIV/AIDS are accompanied by the STD/AIDS Reference Center, on this basis, the sample size (n) was calculated by a Simple Random Sample, with a total of 177 patients, with a margin of error of $7 \%$ and a confidence level of $95 \%$. The sample selection was carried out by randomly contacting the patients, on each examination day on a dental service, during 4 consecutive months until completed contacting the 177 subjects. We included patients with a confirmed diagnosis of HIV infection over 18 years of age and who agreed to participate in the study.

\section{Data collection}

The collection of the data was performed over four months in 2012, after a pilot study in which all the variables were tested.

The QOL data was collected by the HAT-QoL validated instrument developed by Holmes and Shea [16], originally written in English, but translated and validated in Brazil by Galvão [17]. This instrument was selected to be specific for assessing the quality of life of people living with HIV/AIDS, and has good psychometric properties, good internal consistency and evidence of construct validity. The HAT-QoL has 42 items divided into nine domains: General Activity, Sexual Activity, Confidentiality Concerns, Health Concerns, Financial Concern, HIV Awareness, Satisfaction with Life Issues related to medication and Trust in the physician. The response for all items is obtained from a Likert scale that contains: all the time, most of the time, some of the time, part of the time and not at all. In each question, it is noted that only one option best corresponds to characterize the last four weeks experienced by the patient. The scores are calculated according to the answers, and range from one to five, with one representing a worst condition and five in a better state or condition. The scores in each domain are transformed into indices weighing 0-100, and the closer the index is to 100 , the better the quality of life.

The data relating to socio-demographic questions, issues related to HIV and habits were obtained through a structured questionnaire constructed specifically for this study. The socio-demographic variables include: birth, age, gender, color, marital status, education, household income and link to employment. Those related to HIV and habits are: viral load, CD4, date of HIV diagnosis, transmission mode, use of antiretroviral therapy, smoking habits, alcohol, drug use and condom use before and after diagnosis.

The oral health examination was conducted by a calibrated researcher (kappa $>0.81$ for all variables collected), in the dental clinic of the study site. To perform the test we used the probe recommended by the WHO and mouth mirrors. Condition of the teeth, gums and use/need of dentures were evaluated according to the codes and criteria for epidemiological survey of the World Health Organization [18]. For the condition of the teeth, the average number of decayed, missing or obturated teeth was used (DMFT). The periodontal status was verified by the Community Periodontal Index (CPI), which evaluated the presence of bleeding, calculus and periodontal pockets. The codes were: 0 - healthy, 1 bleeding observed after probing, 2- presence of calculus, 3- bag 4-5 mm, 4- bag of $6 \mathrm{~mm}$ or more, X-excluded sextants (less than 2 teeth); 9- no information.

The use of dentures was recorded as follows: 0- no use, 1 - fixed bridge, 2 - more than one fixed bridge, 3 - a removable partial denture, 4- fixed denture + removable 5- total dentures, 9- no information . The need for dentures was also evaluated according to the following codes: 0 - no need, 1 - one element denture, 2- more than one element, 3- combination of dentures, 4- total denture, 9- no information.

\section{Data analysis}

Descriptive analyzes were performed for the sociodemographic characteristics of the population, through the measures of central tendency (simple frequencies, mean and median) and measures of dispersion (standard deviation). The sample involved in the research set the normal distribution of probability, assessed by the Kolmogorov and Smirnov test $(\mathrm{p}=0.100)$ and the hypotheses were verified with the aid of parametric statistics. The region for the rejection or not for any of these hypotheses was considered at a significance level of 0.05 . The statistical analysis of variance (ANOVA) and multiple linear regression tests were conducted with elimination of the non-significant variables. The selection of independent variables for the multiple linear regression models was performed according to a stepwise model. After adjusting the multiple linear regression model, 
with a confidence interval of $95 \%$, the $\mathrm{p}$ - values were estimated. All statistical analyzes were performed using the SPSS version 17.0.

\section{Ethical aspects}

The study was approved by the Ethics Committee on Human Research of the Universidade Estadual Paulista, School of Dentistry of Araçatuba and performed with the understanding and written consent of each participant.

\section{Results}

Of the study participants, more than half of the sample were women $(53.1 \%)$ with a mean age of 42 years. Most were brown (61.6\%) and were not in a stable relationship (48.6\%). Regarding education, $53.1 \%$ had eight years or less of schooling and $7.3 \%$ could not read and write. Of the participants, $20.3 \%$ were not employed and $63.8 \%$ had a monthly income of one to two minimum wages. Regarding the tests, $78.2 \%$ had CD4 counts greater than 350 cells $/ \mathrm{mm} 3$ and $61.6 \%$ undetectable viral load. Regarding the discovery time of HIV diagnosis, 35.0\% responded that there was more than 10 years and $86.4 \%$ of patients were aged 20 to 50 years when they received the result. The transmission by heterosexual relations was $55.9 \%$ and $53.1 \%$ of the respondents said they did not know where they contracted the virus. Most made use of the HAART (77.4\%). Of the patients, $77.4 \%$ were non-smokers, $67.2 \%$ did not consume alcohol and $95 \mid .5 \%$ of the patients said they did not use illicit drugs. Regarding the use of condoms during sexual intercourse, $67.8 \%$ said they always use and $6.8 \%$ said they never use, even after the discovery the HIV.

Patients had a mean DMFT of 17.64 (standard deviation $=7.786)(2.85$ decayed teeth, $\mathrm{SD}=3.58,9.12$ missing teeth, $\mathrm{SD}=7.95$ and 5.67 obturated teeth, $\mathrm{SD}=4.99$ ). The majority of the $\mathrm{HIV}^{+}$patients showed good periodontal status (56.6\%) and $25.3 \%$ had periodontal pockets of 4 to $5 \mathrm{~mm}$. Regarding the use of dentures, $35 \%$ of those surveyed used dentures. Among them, 1.69\% used fixed bridges, $18 \%$ removable partial dentures, $10.7 \%$ total dentures. Regarding the need for dentures, $41.5 \%$ needed dentures in the maxilla and $62 \%$ in the mandible.

In the assessment of the QoL, the domain with the lowest average was the Financial concern (39.4), followed by the Confidentiality Concern (43.2), Sexual activities (55.2) and Health concern (62.88), and the highest averages were: Trust in physician (96.18) and Issues relating to medication (86.54).

The results of the bivariate analysis performed between the averages of the HAT-QoL domains (dependent variables) with the socio-demographic variables, HIV-related aspects, habits and oral health can be seen in Table 1.

For socio-demographic variables there was a statistically significant difference between the ages in the domains of Sexual Activity, Confidentiality concern, Health concern, Financial concern and HIV acceptance. Regarding the sex variable, it was observed that differences between groups were statistically significant in six domains of the HAT-QoL, except in the domains Questions related to medication and Trust in physician.

Regarding personal income, we found that, of the nine domains in only three were observed statistically significant differences: General Activity, Financial concern and Satisfaction with life. In the clinical variables, only the viral load was associated with the domain Questions related to medication and CD4 with General Activity and Health concern.

For the variable related to the transmission of HIV, how transmission occurred was associated with the domains General Activity, Sexual Activity and Satisfaction with life. Regarding the abandonment of treatment we observed statistically significant differences in the domains: General Activity, Confidentiality concern, Health concerns, Financial Concern, HIV acceptance and Satisfaction with life. Alcohol consumption and smoking were associated with Sexual activity. And drug use with the domains Health concerns, Satisfaction with life and Questions related to medication.

Regarding the variables of oral health condition, there were statistically significant differences: number of missing teeth with Confidentiality concern and Health concerns; filled teeth with Confidentiality concern; DMFT with Health concern, use of maxillary denture with Sexual activity, Health concern and Questions related to medication; need for denture with General Activity.

In the multiple linear regression model for the general domain activity, good periodontal status and the good levels of CD4 cells had positive effects on the QoL, while did not have link to employment and the need for dentures had negative effects. Negatively associated to the Sexual activity domain, it did not have link to employment and alcohol consumption (Table 2).

Concerning the Confidentiality domain, older age was positively associated with the best scores, while the fact that being brown or black had a negative association.

In the analysis for the Concern with health domain, being male, of younger age, using dentures and not using illicit drugs were associated with higher scores on the QoL. Concern for the financial domain was associated with the higher score variables: higher level of education, nonsmoking and good periodontal status, while not having link to employment was associated with lower scores.

In the Awareness domain about HIV, good levels of CD4 cells were found, HIV diagnosis of more than 10 years, higher level of education and good periodontal status were associated with the better scores. HAART use was negatively associated with the Satisfaction with life domain, while being male and having good levels of CD4 cells were positively associated. Issues related to 
Table 1 Bivariate analysis of the standard scores of the HAT-QoL domains according to the socio-demographic variables of the 177 participants of the study in Brazil, 2012

\begin{tabular}{|c|c|c|c|c|c|c|c|c|c|}
\hline \multicolumn{10}{|c|}{ HAT-QoL domains } \\
\hline Variables & $\begin{array}{l}\text { General } \\
\text { activity }\end{array}$ & $\begin{array}{l}\text { Sexual } \\
\text { activity }\end{array}$ & $\begin{array}{l}\text { Confidentiality } \\
\text { concern }\end{array}$ & $\begin{array}{l}\text { Health } \\
\text { concern }\end{array}$ & $\begin{array}{l}\text { Financial } \\
\text { concern }\end{array}$ & $\begin{array}{c}\text { HIV } \\
\text { acceptance }\end{array}$ & $\begin{array}{l}\text { Satisfaction } \\
\text { with life }\end{array}$ & $\begin{array}{l}\text { Questions } \\
\text { related to } \\
\text { medication }\end{array}$ & $\begin{array}{c}\text { Trust in } \\
\text { physician }\end{array}$ \\
\hline \multicolumn{10}{|l|}{ Socio-demographic variables } \\
\hline \multicolumn{10}{|l|}{ Age } \\
\hline $18-34$ & 81.8 & 65.4 & 35.1 & 55.6 & 48.4 & 67.7 & 81.8 & 84.2 & 92.6 \\
\hline $35-44$ & 76.4 & 59.5 & 41.2 & 61.8 & 30.7 & 70.8 & 77.2 & 88.6 & 97.7 \\
\hline $45-70$ & 71.8 & 45.2 & 49.8 & 68.0 & 42.2 & 83.2 & 77.7 & 86.6 & 96.7 \\
\hline$p$ value & 0.109 & 0.014 & 0.017 & 0.004 & 0.021 & 0.021 & 0.687 & 0.476 & 0.157 \\
\hline \multicolumn{10}{|l|}{ Sex } \\
\hline Female & 72.0 & 45.8 & 39.0 & 58.8 & 33.1 & 69.0 & 72.0 & 85.1 & 94.9 \\
\hline Male & 80.2 & 65.8 & 47.7 & 67.4 & 46.4 & 81.7 & 85.8 & 88.7 & 97.5 \\
\hline$p$ value & 0.025 & 0.001 & 0.041 & 0.003 & 0.009 & 0.009 & 0.001 & 0.184 & 0.198 \\
\hline \multicolumn{10}{|l|}{ Color } \\
\hline White & 72.3 & 59.9 & 55.5 & 64.8 & 44.4 & 82.5 & 75.6 & 92.3 & 98.9 \\
\hline Black & 76.3 & 52.8 & 40.2 & 63.5 & 42.1 & 76.9 & 81.8 & 87.2 & 99.1 \\
\hline Brown & 76.6 & 54.7 & 40.9 & 62.1 & 37.0 & 72.2 & 78.1 & 85.1 & 94.4 \\
\hline$p$ value & 0.692 & 0.740 & 0.026 & 0.773 & 0.491 & 0.285 & 0.644 & 0.158 & 0.089 \\
\hline \multicolumn{10}{|l|}{ Marital status } \\
\hline Single & 80.2 & 54.8 & 45.2 & 62.9 & 38.8 & 73.8 & 80.0 & 88.0 & 97.9 \\
\hline Married/Consensual union & 74.0 & 70.0 & 46.2 & 66.4 & 38.3 & 85.5 & 82.2 & 82.8 & 97.2 \\
\hline Widowed & 63.0 & 12.8 & 36.5 & 61.1 & 43.7 & 64.7 & 64.9 & 89.8 & 91.6 \\
\hline Separated/Divorced & 74.1 & 50.4 & 48.7 & 64.5 & 45.1 & 77.9 & 76.8 & 85.9 & 90.8 \\
\hline$p$ value & 0.114 & 0.000 & 0.216 & 0.687 & 0.900 & 0.312 & 0.425 & 0.722 & 0.177 \\
\hline \multicolumn{10}{|l|}{ Education } \\
\hline Illiterate & 62.6 & 50.6 & 42.6 & 66.1 & 18.3 & 69.9 & 76.0 & 78.8 & 93.6 \\
\hline 8 or $<$ of study & 76.8 & 50.5 & 44.3 & 61.7 & 37.3 & 71.6 & 78.7 & 86.6 & 96.7 \\
\hline 9 years or more of study & 75.1 & 57.7 & 42.6 & 62.7 & 42.4 & 79.5 & 76.2 & 89.1 & 96.2 \\
\hline$p$ value & 0.162 & 0.079 & 0.921 & 0.683 & 0.015 & 0.325 & 0.663 & 0.335 & 0.834 \\
\hline \multicolumn{10}{|l|}{ Link to employment } \\
\hline Employed & 84.4 & 69.7 & 36.7 & 64.4 & 46.7 & 77.9 & 85.3 & 88.7 & 95.9 \\
\hline Not employed & 67.9 & 41.8 & 49.2 & 61.4 & 32.5 & 72.2 & 72.2 & 85.0 & 96.3 \\
\hline$p$ value & 0.000 & 0.000 & 0.002 & 0.296 & 0.005 & 0.246 & 0.002 & 0.167 & 0.839 \\
\hline \multicolumn{10}{|l|}{ Personal income } \\
\hline Less than $1 \mathrm{MS}$ & 57.0 & 41.6 & 52.5 & 56.1 & 18.0 & 72.2 & 60.5 & 89.5 & 92.1 \\
\hline 1 to $2 \mathrm{MS}$ & 77.0 & 53.1 & 41.0 & 63.8 & 39.2 & 74.1 & 80.2 & 87.1 & 96.9 \\
\hline 3 to $4 \mathrm{Ms}$ & 83.7 & 68.6 & 47.2 & 66.2 & 53.5 & 81.3 & 82.7 & 86.3 & 97.4 \\
\hline More than 4 MS & 84.4 & 55.0 & 36.0 & 61.0 & 49.0 & 76.8 & 94.4 & 85.0 & 96.6 \\
\hline$p$ value & 0.002 & 0.146 & 0.684 & 0.557 & 0.006 & 0.572 & 0.003 & 0.931 & 0.123 \\
\hline \multicolumn{10}{|c|}{ Variables related to HIV and habits } \\
\hline \multicolumn{10}{|l|}{$\mathrm{VL}$} \\
\hline Undetectable & 77.4 & 53.9 & 46.1 & 65.2 & 39.3 & 78.9 & 81.6 & 88.3 & 97.7 \\
\hline$<10000$ & 73.9 & 56.9 & 42.8 & 62.6 & 44.1 & 68.8 & 82.1 & 90.7 & 96.3 \\
\hline$>10000$ & 74.2 & 59.0 & 38.3 & 60.6 & 38.3 & 70.3 & 70.0 & 79.8 & 91.8 \\
\hline
\end{tabular}


Table 1 Bivariate analysis of the standard scores of the HAT-QoL domains according to the socio-demographic variables of the 177 participants of the study in Brazil, 2012 (Continued)

\begin{tabular}{|c|c|c|c|c|c|c|c|c|c|}
\hline$p$ value & 0.689 & 0.757 & 0.290 & 0.399 & 0.796 & 0.196 & 0.062 & 0.016 & 0.059 \\
\hline \multicolumn{10}{|l|}{ CD4 } \\
\hline$<200$ & 57.4 & 59.2 & 47.2 & 72.2 & 29.8 & 79.6 & 60.5 & 82.6 & 98.1 \\
\hline From 200 to 350 & 72.9 & 60.4 & 43.3 & 54.1 & 39.8 & 63.4 & 73.0 & 80.7 & 91.0 \\
\hline$>350$ & 76.0 & 55.6 & 43.4 & 63.7 & 39.5 & 75.4 & 78.5 & 86.4 & 96.0 \\
\hline$p$ value & 0.039 & 0.722 & 0.915 & 0.006 & 0.680 & 0.096 & 0.058 & 0.145 & 0.112 \\
\hline \multicolumn{10}{|c|}{ Years since Discovering HIV } \\
\hline Less than 1 year & 72.7 & 52.0 & 31.2 & 41.2 & 39.1 & 61.3 & 70.3 & 78.7 & 86.5 \\
\hline From 1 to 5 years & 80.3 & 63.7 & 39.5 & 65.5 & 42.6 & 70.0 & 79.6 & 86.5 & 94.5 \\
\hline More than 5 years & 78.0 & 58.1 & 42.0 & 66.0 & 40.2 & 77.6 & 84.6 & 89.2 & 96.9 \\
\hline$p$ value & 0.155 & 0.089 & 0.146 & 0.003 & 0.774 & 0.294 & 0.126 & 0.447 & 0.098 \\
\hline \multicolumn{10}{|l|}{ Transmission mode } \\
\hline $\begin{array}{l}\text { Heterosexual } \\
\text { relations }\end{array}$ & 71.4 & 49.3 & 41.7 & 59.6 & 36.0 & 69.8 & 74.9 & 83.3 & 95.1 \\
\hline $\begin{array}{l}\text { Homosexual } \\
\text { relations }\end{array}$ & 84.9 & 68.5 & 46.6 & 67.0 & 50.6 & 87.7 & 88.1 & 90.2 & 96.7 \\
\hline Use of drugs & 100.0 & 100.0 & 80.0 & 45.0 & 0 & 100.0 & 81.0 & 81.0 & 100.0 \\
\hline Blood transfusion & 69.5 & 0 & 57.5 & 70.0 & 44.0 & 100.0 & 100.0 & 94.0 & 100.0 \\
\hline Mother to child & 100.0 & 50.0 & 70.0 & 77.5 & 84.5 & 100.0 & 94.0 & 100.0 & 100.0 \\
\hline$p$ value & 0.043 & 0.026 & 0.370 & 0.146 & 0.065 & 0.046 & 0.167 & 0.096 & 0.891 \\
\hline \multicolumn{10}{|c|}{ From whom contracted } \\
\hline Actual partner & 79.1 & 55.5 & 28.3 & 50.8 & 42.8 & 86.1 & 68.1 & 88.5 & 77.8 \\
\hline Ex partner & 57.8 & 26.2 & 45.7 & 57.1 & 27.1 & 64.8 & 61.6 & 84.5 & 92.5 \\
\hline Mother & 100.0 & 50.0 & 70.0 & 77.5 & 84.5 & 100.0 & 94.0 & 100.0 & 100.0 \\
\hline Do not know & 79.1 & 62.0 & 43.8 & 65.4 & 40.0 & 77.8 & 81.9 & 89.4 & 98.6 \\
\hline$p$ value & 0.026 & 0.012 & 0.075 & 0.323 & 0.203 & 0.247 & 0.124 & 0.349 & 0.006 \\
\hline \multicolumn{10}{|l|}{ Use of HAART } \\
\hline Yes & 76.3 & 54.7 & 45.4 & 63.3 & 39.7 & 77.5 & 80.8 & 88.4 & 97.8 \\
\hline No & 74.0 & 57.0 & 35.8 & 61.2 & 38.1 & 66.2 & 70.5 & 81.3 & 90.6 \\
\hline$p$ value & 0.600 & 0.742 & 0.053 & 0.547 & 0.797 & 0.051 & 0.040 & 0.028 & 0.003 \\
\hline \multicolumn{10}{|l|}{ Non use of HAART } \\
\hline Yes & 64.0 & 49.4 & 53.7 & 57.1 & 22.0 & 61.4 & 65.6 & 83.0 & 97.9 \\
\hline No & 80.6 & 55.9 & 43.0 & 65.5 & 46.0 & 82.3 & 85.8 & 90.1 & 97.7 \\
\hline$p$ value & 0.000 & 0.406 & 0.048 & 0.029 & 0.000 & 0.000 & 0.000 & 0.075 & 0.930 \\
\hline \multicolumn{10}{|l|}{ Smokers } \\
\hline Yes & 75.1 & 63.5 & 39.6 & 62.7 & 25.9 & 79.1 & 73.1 & 83.7 & 98.7 \\
\hline No & 76.0 & 52.8 & 44.3 & 62.9 & 43.3 & 73.7 & 80.1 & 87.7 & 95.4 \\
\hline$p$ value & 0.978 & 0.025 & 0.721 & 0.519 & 0.602 & 0.816 & 0.930 & 0.064 & 0.103 \\
\hline \multicolumn{10}{|c|}{ Consumes alcoholic drinks } \\
\hline Yes & 77.7 & 65.3 & 38.6 & 60.4 & 33.2 & 75.4 & 78.5 & 85.1 & 95.8 \\
\hline No & 74.9 & 50.3 & 45.5 & 64.0 & 42.3 & 74.7 & 78.5 & 87.6 & 96.3 \\
\hline$p$ value & 0.474 & 0.015 & 0.117 & 0.242 & 0.094 & 0.897 & 0.993 & 0.379 & 0.810 \\
\hline \multicolumn{10}{|l|}{ Use of illicit drugs } \\
\hline Yes & 71.8 & 50.8 & 55.0 & 43.7 & 26.6 & 61.5 & 55.3 & 68.7 & 89.6 \\
\hline No & 76.0 & 55.4 & 42.6 & 63.7 & 40.0 & 75.6 & 79.6 & 87.6 & 96.4 \\
\hline
\end{tabular}


Table 1 Bivariate analysis of the standard scores of the HAT-QoL domains according to the socio-demographic variables of the 177 participants of the study in Brazil, 2012 (Continued)

\begin{tabular}{|c|c|c|c|c|c|c|c|c|c|}
\hline$p$ value & 0.638 & 0.745 & 0.215 & 0.004 & 0.277 & 0.229 & 0.016 & 0.003 & 0.162 \\
\hline \multicolumn{10}{|c|}{ Used contraception before HIV } \\
\hline Never & 74.8 & 47.5 & 46.7 & 63.9 & 36.8 & 73.4 & 78.2 & 88.8 & 98.2 \\
\hline Always & 74.7 & 64.6 & 45.0 & 77.5 & 46.8 & 75.0 & 68.0 & 85.0 & 91.6 \\
\hline Sometimes & 76.4 & 64.6 & 45.0 & 77.5 & 78.5 & 100.0 & 94.0 & 100.0 & 100.0 \\
\hline$p$ value & 0.841 & 0.000 & 0.249 & 0.603 & 0.380 & 0.286 & 0.455 & 0.678 & 0.055 \\
\hline \multicolumn{10}{|c|}{ Oral health variables } \\
\hline \multicolumn{10}{|l|}{ Caries } \\
\hline$\leq 3$ & 75.5 & 52.9 & 42.0 & 62.5 & 62.5 & 40.6 & 78.6 & 86.8 & 96.6 \\
\hline$>3$ & 76.5 & 60.2 & 45.8 & 63.5 & 63.5 & 36.5 & 78.2 & 86.7 & 95.1 \\
\hline$p$ value & 0.810 & 0.24 & 0.403 & 0.761 & 0.461 & 0.995 & 0.927 & 0.972 & 0.497 \\
\hline \multicolumn{10}{|l|}{ Teeth loss } \\
\hline$\leq 9$ & 76.2 & 58.8 & 40.5 & 60.3 & 39.2 & 74.6 & 79.6 & 86.5 & 95.2 \\
\hline$>9$ & 75.6 & 49.0 & 49.3 & 66.5 & 41.0 & 77.6 & 77.7 & 87.5 & 97.9 \\
\hline$p$ value & 0.861 & 0.106 & 0.036 & 0.039 & 0.076 & 0.544 & 0.671 & 0.725 & 0.191 \\
\hline \multicolumn{10}{|l|}{ Obturated } \\
\hline$\leq 6$ & 77.1 & 57.8 & 47.0 & 64.4 & 41.2 & 76.8 & 80.5 & 86.1 & 97.7 \\
\hline$>6$ & 73.9 & 50.2 & 38.2 & 59.5 & 37.5 & 73.7 & 76.0 & 88.3 & 97.1 \\
\hline$p$ value & 0.398 & 0.212 & 0.041 & 0.109 & 0.487 & 0.540 & 0.301 & 0.436 & 0.516 \\
\hline \multicolumn{10}{|l|}{ DMFT index } \\
\hline$\leq 18$ & 78.0 & 58.1 & 41.4 & 59.8 & 39.4 & 71.8 & 82.5 & 84.4 & 94.6 \\
\hline$>18$ & 73.6 & 52.2 & 45.1 & 66.0 & 39.3 & 78.2 & 74.4 & 89.3 & 97.7 \\
\hline$p$ value & 0.231 & 0.315 & 0.374 & 0.033 & 0.977 & 0.191 & 0.055 & 0.069 & 0.120 \\
\hline \multicolumn{10}{|l|}{$\mathrm{PCl}$} \\
\hline$\leq 2$ & 41.6 & 33.3 & 50.0 & 50.0 & 33.3 & 44.3 & 47.6 & 79.0 & 100.0 \\
\hline$>2$ & 83.4 & 50.3 & 40.6 & 64.3 & 48.4 & 73.5 & 82.9 & 90.3 & 98.5 \\
\hline$p$ value & 0.022 & 0.759 & 0.304 & 0.707 & 0.273 & 0.182 & 0.278 & 0.074 & 0.445 \\
\hline \multicolumn{10}{|c|}{ Use of dentures } \\
\hline Yes & 76.8 & 44.9 & 45.3 & 68.6 & 43.8 & 80.1 & 81.5 & 91.2 & 99.1 \\
\hline No & 75.4 & 59.2 & 42.4 & 60.6 & 37.6 & 72.9 & 77.3 & 85.1 & 95.0 \\
\hline$p$ value & 0.751 & 0.026 & 0.533 & 0.013 & 0.273 & 0.186 & 0.379 & 0.041 & 0.066 \\
\hline \multicolumn{10}{|c|}{ Denture need } \\
\hline Yes & 72.2 & 50.5 & 44.7 & 62.8 & 36.5 & 72.8 & 75.8 & 87.0 & 97.1 \\
\hline No & 81.4 & 62.1 & 40.6 & 62.6 & 44.6 & 78.3 & 82.6 & 86.3 & 94.5 \\
\hline$p$ value & 0.014 & 0.053 & 0.338 & 0.927 & 0.121 & 0.276 & 0.116 & 0.817 & 0.211 \\
\hline
\end{tabular}

variable drugs, not using illicit drugs and not having been infected through sex were positively associated, while high viral load was negatively correlated, as to the Trust the physician domain, not using the HAART was negatively associated.

\section{Discussion}

The results of this study showed that the oral health status of the participants was worse than the national average of Brazilians [19], with a DMFT index of 17.64, with a mean of 9 missing teeth and 3 decayed teeth per person, although large associations of the oral health variables in the quality of life domains were not observed. This can be explained by the fact that oral problems, in most cases, does not cause a threat to life, being, in general, acute episodes and readily treatable. Thus, their impact on the quality of life may not be obvious and often minimized by the context of other more 
Table 2 Multiple linear regression for the quality of life variable for the $\mathbf{1 7 7}$ participants of the study

\begin{tabular}{|c|c|c|c|}
\hline $\begin{array}{l}\text { Quality of life } \\
\text { domains of } \\
\text { the HAT-Qol }\end{array}$ & Explicative variables & B & $p$ value \\
\hline \multirow{4}{*}{$\begin{array}{l}\text { General activity } \\
\left(r^{2}=0.506\right)\end{array}$} & No link to employment & -16.375 & 0.000 \\
\hline & Good periodontal status & 6.025 & 0.000 \\
\hline & Good levels of CD4 & 9.328 & 0.007 \\
\hline & Need for dentures & -8.368 & 0.025 \\
\hline \multirow{2}{*}{$\begin{array}{l}\text { Sexual activity } \\
\left(r^{2}=0.318\right)\end{array}$} & No link to employment & -19.943 & 0.001 \\
\hline & $\begin{array}{l}\text { Consumes alcoholic } \\
\text { beverages }\end{array}$ & -12.758 & 0.041 \\
\hline \multirow{2}{*}{$\begin{array}{l}\text { Confidentiality } \\
\text { concerns } \\
\left(r^{2}=0.311\right)\end{array}$} & Older age & 7.534 & 0.007 \\
\hline & Brown or black & -5.684 & 0.045 \\
\hline \multirow{4}{*}{$\begin{array}{l}\text { Health concerns } \\
\left(r^{2}=0.437\right)\end{array}$} & Of the masculine sex & 10.289 & 0.001 \\
\hline & Denture user & 8.675 & 0.016 \\
\hline & Do not use illicit drugs & 20.722 & 0.006 \\
\hline & Younger age & 3.890 & 0.046 \\
\hline \multirow{4}{*}{$\begin{array}{l}\text { Financial concerns } \\
\left(r^{2}=0.462\right)\end{array}$} & Higher level of education & 10.430 & 0.002 \\
\hline & Non smoker & 19.784 & 0.002 \\
\hline & Good periodontal status & 6.995 & 0.002 \\
\hline & No link to employment & -15.601 & 0.004 \\
\hline \multirow{4}{*}{$\begin{array}{l}\text { HIV acceptance } \\
\left(r^{2}=0.359\right)\end{array}$} & Good levels of CD4 & 11.323 & 0.024 \\
\hline & $\begin{array}{l}\text { HIV diagnosed more } \\
\text { than } 10 \text { yrs yrsanos }\end{array}$ & 6.927 & 0.018 \\
\hline & Higher level of education & 10.529 & 0.002 \\
\hline & Good periodontal status & 5.941 & 0.008 \\
\hline \multirow{3}{*}{$\begin{array}{l}\text { Satisfaction with } \\
\text { life }\left(r^{2}=0.390\right)\end{array}$} & Of the masculine sex & 15.993 & 0.000 \\
\hline & Good levels of CD4 & 14.332 & 0.001 \\
\hline & Use of HAART & -12.813 & 0.016 \\
\hline \multirow{3}{*}{$\begin{array}{l}\text { Questions related } \\
\text { to medication } \\
\left(r^{2}=0.334\right)\end{array}$} & Use illicit drugs & 18.609 & 0.013 \\
\hline & Sexual transmission mode & 1.709 & 0.020 \\
\hline & High levels of $\mathrm{VL}$ & -3.590 & 0.035 \\
\hline $\begin{array}{l}\text { Trust in the } \\
\text { physician } \\
\left(r^{2}=0.226\right)\end{array}$ & Non use of HAART & -7.781 & 0.006 \\
\hline
\end{tabular}

$B=$ Regression model coefficient. $r=$ Determination coefficient. Brazil. 2012.

serious chronic conditions [20]. In addition, low socioeconomic status and low education of this population put them in disadvantage in relation to oral health problems due to lack of access to dental care, and lack of information about the prevention of oral diseases. And that's why they do not give much importance to oral health, which also explains the low impact of oral health on quality of life [21,22].

In Brazil, few studies have reported the experience of dental caries in people living with HIV/AIDS and those that were made most were related to children. It is known that dental caries is an infectious disease and the various side effects of antiretroviral therapy may contribute to inadequate oral hygiene and diet, that being said, HIV infection appears to be a risk factor for caries [23]. This can be observed by the results of the oral health of this study, as well as others performed with people living with HIV/AIDS, where high levels of DMFT were reported. And these numbers are far from the goals proposed by the WHO for the year 2010, where the presence of 20 or more teeth in the oral cavity for $96 \%$ of the individuals with no missing teeth, at 18 years of age [24-26].

Oral diseases and HIV infection have a higher impact on disadvantaged and socially marginalized populations [27] similar to this study, where the majority of the respondents were poor and had little schooling. Another important aspect with regard to the transmission mode, which largely consisted of heterosexual relationships, is in agreement with the epidemiological profile of HIV a few years ago: heterosexuals and women, impoverishment and internalization $[28,29]$.

The number of decayed and missing teeth and the need for dentures characterize the sample as a group in great need of dental care [30] and in Brazil, access to free dentistry treatment is still complicated, there is a long waiting list for patients with oral problems and they do not have the financial means to afford a private service, and give up dental care. In addition, the Brazilian population shows that the demand for dental care happens when the dental disease is already at an advanced stage, with irritation and pain. A direct consequence of this systematic exclusion of services, are dental extractions which, in most cases, could be avoided [31].

In the analysis of the scores of the quality of life, the results showed that the lowest averages were: Financial concern, Confidentiality concern, Sexual activities and Health concerns, results that corroborate with the findings of other studies using the HAT -QoL scale $[16,17,32]$.

The average obtained (39.4) in the Financial concern domain probably was the low per capita income of the respondents, which hinders the survival of the individual. This may indicate that income, in spite of holding their value on living conditions and services, can influence the state of health, which further hinders their integration into the labor market [33]. People living with HIV/AIDS who have no link to employment have a poorer quality of life than those who work, this is also observed in another study [34]. Therefore, the chronicity of the disease brings new changes, including issues related to occupation, employment appears to not only have the importance of financial benefit, but is a form of social, emotional and identity inclusion as well [35].

The Confidentiality concern is a very common situation among these individuals, which happens because of the fear of being seen as having a disease still very 
stigmatized by society. That means they have a life of duplicity, because only a few people from their neighborhood are chosen to know about their HIV status [32]. This concern even affects the demand for health care because these patients stop going, or looking for the dentist too late, for fear of having to report that they have the HIV virus and suffer prejudice due to the unpreparedness of the professional, this makes these patients prone to having major problems related to oral health, this can be observed in the significant association of the variables of decayed and teeth loss with the Confidentiality concern domain [36].

Life with HIV/AIDS brings changes in the sexual activity of persons, and the conditions under which they find themselves due to the infection, leading to a fear of sexual relationships, which makes them avoid relationships, even though they have sexual desires [37]. This implies the involvement of the Sexual activity domain on the quality of life and the fact that there is no link to employment and alcohol consumption further strengthens a poorer quality of life.

The Health concern domain investigates the restlessness of the respondents living with the virus and its consequences, and self-assessment in relation to health, knowledge of laboratory parameters and concern with a prognosis of death situations that possibly hinder wellbeing $[17,38]$. From this perspective, in this study the year of HIV diagnosis was associated with this domain, for the reason that people with recent discovery of the infection do not accept the fact that the disease, which leads to discouragement with life and health care, and implies low scores. In the multiple linear regression, the fact of not using illicit drugs had a positive association in this field, in addition to using dentures, which demonstrates the care of individuals in their health and wellbeing.

The periodontal status of the participants of the study was good on the most part, with the Community Periodontal Index below the expected average, as well as the study by Lemos et al., who found a low frequency of periodontal disease in people living with HIV/AIDS, and the condition of systemic infection an important factor in maintaining the periodontal status. Individuals with a more advanced state of infection presented greater problems in the periodontium. This positively influences the periodontal health on the quality of life in more than one domain, as observed in the multivariate analysis $[39,40]$.

The found results presented the socio-demographic and clinical characteristics of these individuals similar to other surveys conducted with a Brazilian population living with HIV/AIDS $[17,34,35]$. There are some limitations to this study, such as the voluntary participation of the respondents, which may have had more individuals concerned about the oral and general health and higher education. The research is cross-sectional, which precludes causal inferences. Due to the anonymous nature of the study, it was not possible to collect any information about those who did not answer the questionnaire completely. With regards to the quality of life instrument, though it may be validated in the Portuguese language, the educational level of the respondents may have had an influence on the responses in which the participants responded without even understanding the question.

Despite these limitations, the study shows that there are many factors that influence the quality of life of people living with HIV/AIDS, and the socioeconomic conditions and inadequate oral health negatively influence the quality of life of these individuals.

\section{Competing interests}

The authors declare that they have no competing interests.

\section{Authors' contributions}

GBS, CASG and AJIG designed the study, gathered the information, performed the statistical analysis and wrote the first draft of the manuscript. TASR designed the form for data gathering and supervised the statistical analysis. All authors read and approved the final manuscript.

\section{Acknowledgements}

The research was supported by the STD/AIDS Reference Center. Thanks to the patient's participation in this study. Thanks to Dr Cláudio José Ribeiro da silva for his help in data collection.

Received: 6 August 2013 Accepted: 19 February 2014

Published: 1 March 2014

\section{References}

1. World Health Organization\&UNAIDS: AIDS Epidemic Update. Geneva: Joint United Nations Programme on HIV/AIDS and World Health Organization; 2009.

2. Brasil Ministério da Saúde: Boletim Epidemiológico Aids - DST: versão preliminar. Brasília: Ministério da Saúde; 2012

3. Weiss RA: Special anniversary review: twenty-five years of human immunodeficiency virus research: successes and challenges. Clin Exp Immunol 2008 , 15:201-210.

4. The Antiretroviral Therapy Cohort Collaboration: Life expectancy of individuals on combination antiretroviral therapy in high-income countries: a collaborative analysis of 14 cohort studies. Lancet 2008, 372:293-299.

5. Locker D: Concepts of oral health, disease and the quality of life. In Measuring oral health and quality of life (Edited by: Slade GD). Chapel Hill: University of North Carolina: Dental Ecolog; 1997:11-24.

6. Allen PF: Assessment of oral health related quality of life. Health Qual Life Outocomes 2003, 1:40.

7. Locker D, Gibson B: Discrepancies between self-ratings of and satisfaction with oral health in two older adult populations. Community Dent Oral Epidemiol 2005, 33:280-288.

8. Kotzer RD, Lawrence HP, Clovis JB, Matthews DC: Oral health-related quality of life in an aging Canadian population. Health Qual Life Outcomes 2012, 10:50.

9. Heslin KC, Cunningham WE, Marcus M, Coulter I, Freed J, Der-Martirosian C, Bozzette SA, Shapiro MF, Morton SC, Andersen RM: A comparison of unmet needs for dental and medical care among persons with HIV infection receiving care in the United States. J Public Health Dent 2001, 61:14-21.

10. Shiboski CH, Cohen M, Weber K, Shansky A, Malvin K, Greenblatt RM: Factors associated with use of dental services among HIV-infected and high-risk uninfected women. J Am Dent Assoc 2005, 136:1242-1255.

11. Dobalian A, Andersen RM, Stein JA, Hays RD, Cunningham WE, Marcus M: The impact of HIV on oral health and subsequent use of dental services. J Public Health Dent 2003, 63:78-85.

12. Sanders AE, Spencer AJ, Slade GD: Evaluating the role of dental behaviour in oral health inequalities. Community Dent Oral Epidemiol 2006, 34:71-79. 
13. Diz DP, Scully C: Antiretroviral therapy: effects on orofacial health and health care. Oral Dis 2013. doi:10.1111/odi.12093.

14. Wang TF, Chou C, Shu Y: Assessing the effects of oral health-related variables onquality of lifein Taiwanese adults. Qual Life Res 2013, 22:811-825

15. Massarente DB, Domaneschi C, Marques HH, Andrade SB, Goursand D, Antunes $J$ : Oral health related quality of life of paediatric patients with AIDS. BMC Oral Health 2011, 11:2.

16. Holmes WC, Shea JA: Performance of a new, HIV/AIDS-targeted quality of life (HAT-QoL) instrument in asymptomatic seropositive individuals. Qual Life Res 1997, 6:561-571.

17. Galvão MTG, Cerqueira ATAR, Marcondes-Machadon J: Evaluation of quality of life among women with HIV/AIDS using HAT-Qol. Cad Saúdepública 2004, 20:430-437.

18. World Health Organization: Oral Health Surveys: Basic Methods. 4th edition. Geneva: World Health Organization; 1997.

19. Brasil. Ministério da Saúde: Projeto SB Brasil 2010: Nota Para a Imprensa. Brasília: Ministério da Saúde; 2010.

20. Reisine ST: The impact of dental conditions on social functioning and the quality of life. Ann Rev Public Health 1988, 9:1-19.

21. Fontanive $V$, Abegg C, Tsakos G, Oliveira M: The association between clinical oral health and general quality of life: a population-based study of individuals aged 50-74 in Southern Brazil. Community Dent Oral Epidemiol 2013, 41:154-162.

22. Brennan DS: Oral Health Impact Profile, EuroQol, and assessment of quality of life instruments as quality of life and health-utility measures of oral health. Eur J Oral Sci 2013, 121:188-193.

23. Aleixo RQ, Scherma AP, Guimarães G, Cortelli JR, Cortelli SC: DMFT index and oral mucosal lesions associated with HIV infection: cross-sectional study in Porto Velho, Amazonian Region - Brazil. Braz J Infect Dis 2010, 14:449-456.

24. Bretz WA, Flaitz C, Moretti A, Corby P, Sdineider LG, Nichols CM: Medication usage and dental caries outcome-related variables in HIV/AIDS patients. AIDS Patient Care STDS 2000, 14:549-554.

25. Phelan JA, Mulligan R, Nelson E, Brunelle J, Alves MEAF, Navazesh M, Greenspan D: Dental caries in HIV seropositive women. J Dent Res 2004 , 83:869-873

26. Silveira FM, Rangel M: Biopsy social profile of the patients of the program of awareness of the oral health of HIV/AIDS sufferers of the Hospital UniversitárioAntônio Pedro HUAP/UFF. Pesqui Bras Odontopediatriaclín Integr 2004, 4:221-226.

27. Robinson PG: Implications of HIV disease for oral health services. Adv Dent Res 2006, 19:73-79.

28. Brito AM, Castilho EA, Szwarcwald CL: AIDS and HIV infection in Brazil: a multifaceted epidemicRev. Soc Bras Med Trop 2001, 34:207-217.

29. Mulligan R, Seirawan $H$, Alves ME, Navazesh M, Phelan JA, Greenspan D, Greenspan JS, Mack WJ: Oral health-related quality of life among HIV-infected and at-risk women. Community Dent Oral Epidemiol 2008, 36:549-557.

30. Engeland CG, Jang P, Alves M, Marucha PT, Califano J: HIV infection and tooth loss. Oral Surg Oral Med Oral Pathol Oral Radiol Endod 2008, 105:321-326.

31. Barbato PR, Nagano HCM, Zanchet FN, Boing AF, Peres MA: Perda dentária e fatores sociais, demográficos e de services associados em adultos brasileiros: uma análise dos dados do estudo Epidemiológico Nacional (Projeto SB Brasil 2002-2003). Cad Saúde Pública 2007, 23:1803-1814.

32. Reis RK, Santos CB, Spadoti Dantas RA, Gir E: Quality of life, sociodemographicfactores and sexuality of people living with HIV/AIDS. Texto Contextoenferm 2011, 20:365-375.

33. Jia H, Uphold CR, Zheng Y, Wu S, Chen GJ, Findley K, Duncan PW: A further investigation of health related quality of life over time among men with HIV infection in the HAART era. Qual Lif Res 2007, 16:961-968.

34. Santos EMC, Franca I Jr, Lopes F: Quality of life of people living with HIV/ AIDS in São Paulo. Rev Saúdepública 2007, 41:64-71.

35. Reis RK, Santos CB, Gir E: Quality of life among Brazilian women living with HIV/Aids. Aids Care 2012, 24:626-634.

36. Garbin CAS, Garbin AJl, Moimaz SAS, Carmo MP: Bioética e HIV/AIDS: discriminação no atendimento aos portadores. Rev Bioét 2009, 17:511-522.

37. Grimberg M: Género y vih/sida:unanálisis de los diferenciales de género em la experiencia de vivir con VIH. Cuad Méd Soc 2000, 78:41-54.

38. Herrmann S, McKinnon E, Hyland NB, Lalanne C, Mallal S, Nolan D, Chassany O, Duracinsky M: HIV-related stigma and physical symptoms have a persistent influence on health-related quality of life in Australians with HIV infection. Health Qual Life Outcomes 2013, 11:56.

39. Lemos SS, Oliveira FA, Vencio EF: Periodontal disease and oral hygiene benefits in HIV seropositive and AIDS patients. Medicina Oral Patologia Oral y Cirurgía Bucal 2010, 15:417-421

40. Liberali S, Coates E, Freeman A, Logan R, Jamieson L, Mejia G: Oral conditions and their social impact among HIV dental patients, 18 years on. Aust Dent J 2013, 58:18-25.

doi:10.1186/1477-7525-12-28

Cite this article as: Soares et al:: Oral health associated with quality of life of people living with HIV/AIDS in Brazil. Health and Quality of Life

Outcomes 2014 12:28.

\section{Submit your next manuscript to BioMed Central and take full advantage of:}

- Convenient online submission

- Thorough peer review

- No space constraints or color figure charges

- Immediate publication on acceptance

- Inclusion in PubMed, CAS, Scopus and Google Scholar

- Research which is freely available for redistribution 